\title{
O êxodo é (ainda) um paradigma político de libertação? Algumas suspeitas filosóficas e teológicas desde junho de 2013
}

\author{
Daniel Santos Souza*
}

\section{Resumo}

As teologias latino-americanas da libertação foram construídas a partir do paradigma do êxodo. Embora alguns teólogos, como Gustavo Gutiérrez (1987), tenham proposto outras aproximações paradigmáticas, é sobre o esquema opressão-libertação que se organiza majoritariamente esse método teológico, esse modo de viver uma espiritualidade, esse modo de imaginar Deus e ensaiar projetos políticos. Retomar esse paradigma me parece importante para repensarmos os projetos históricos e as suas relações com o estado-nação no contexto da América Latina. Por isso, em um exercício de revisão das teologias da libertação, apresento nesse artigo a possibilidade de se repensar esse paradigma a partir das inquietações provocadas pelos acontecimentos de junho de 2013 no Brasil, colocando em questão algumas marcas centrais no êxodo como paradigma de libertação: o soberano (como modelo de Deus), o povo-nação, a posse da terra como projeto, o pobre como sujeito histórico, o opressor como o ídolo e a operatividade como prática.

Palavras-chave: Êxodo; Filosofia política; Teologia política; Junho de 2013; Teologias da libertação.

\section{Is the exodus (still) a political paradigm of liberation? Some philosophical and theological suspicions since June 2013}

\footnotetext{
Abstract

Latin American liberation theologies were built on the exodus paradigm. Although some theologians, such as Gustavo Gutiérrez (1987), have proposed other paradigmatic approaches, the oppression-liberation scheme organizes this theological method, this way of living a spirituality, this way of imagining God, and rehearsing political projects. Retrieving this paradigm seems to me important to rethink historical projects and

Doutor (2019) e Mestre em Ciências da Religião (2013), Licenciado em Filosofia (2011) e Bacharel em Teologia (2010) pela Universidade Metodista de São Paulo (UMESP). Participa do Grupo de Pesquisa: Perspectivas Críticas da Filosofia Moderna e Contemporânea (UFABC/CNPq). Atualmente, é Pesquisador Doutor Colaborador na Universidade Federal do $\mathrm{ABC}$ (UFABC), em uma investigação de pós-doutorado sobre as formas-de-vida nas ocupações de moradia no centro da cidade de São Paulo.
} 
their relations with the nation-state in the context of Latin America. For this reason, in an exercise to review liberation theologies, I present in this article the possibility of rethinking this paradigm based on the concerns caused by the events of June 2013 in Brazil, calling into question some central marks in the exodus as a paradigm of liberation: the sovereign (as a model of God), the nation as a people, the possession of the land as a project, the poor as a historical subject, the oppressor as the idol and operativeness as a practice.

Keywords: Exodus; Political philosophy; Political theology; June 2013; Liberation theologies.

\section{¿Es el éxodo (todavía) un paradigma político de liberación? \\ Algunas sospechas filosóficas y teológicas desde junio de 2013}

\section{Resumen}

Las teologías de la liberación latinoamericanas se construyeron sobre el paradigma del éxodo. Si bien algunos teólogos, como Gustavo Gutiérrez (1987), han propuesto otros enfoques paradigmáticos, se trata del esquema de opresión-liberación que organiza este método teológico, esta forma de vivir una espiritualidad, esta forma de imaginar a Dios y de ensayar proyectos políticos. Retomar este paradigma nos parece importante para repensar los proyectos históricos y sus relaciones con el Estado-nación en el contexto de América Latina. Por ello, en un ejercicio de revisión de las teologías de la liberación, presento en este artículo la posibilidad de repensar este paradigma a partir de las inquietudes que suscitaron los hechos de junio de 2013 en Brasil, cuestionando algunas marcas centrales del éxodo como paradigma de la liberación: el soberano (como modelo de Dios), la nación-pueblo, la posesión de la tierra como proyecto, el pobre como sujeto histórico, el opresor como ídolo y la operatividad como práctica.

Palabras claves: Éxodo; Filosofia politica; Teología política; Junio de 2013; Teologías de la liberación.

para fellipe dos anjos.

\section{i. Para começar: junho como a "dobra" que provoca o pensamento}

O que provoca o pensamento? O que nos levar a ensaiar modos de vida? Quais elementos, corpos e processos nos empurram para imaginar possibilidades prático-teóricas? No texto "A periferia contra o estado? Para escapar das ciências tristes! Criemos outras possibilidades” (2017), há uma tentativa de reflexão sobre um modo de produção do conhecimento como "pesquisaluta”. Como ponto de partida, a inquietação é ser um(a) pesquisador(a) que seja "capaz de farejar onde estão as dobras que podem nos mover, 
O êxodo é (ainda) um paradigma político de libertação? 399 Algumas suspeitas filosóficas e teológicas desde junho de 2013

as questões que os poderes dominantes tentam esconder a qualquer custo, que possam produzir interferências no sistema hierarquizado de saberes e que possam, de fato, sonhar com outros mundos mas também praticá-los" (MORAES \& TIBLE, 2017). É colocar o pensamento em movimento e deixar-se interpelar e arrastar. Os acontecimentos de junho de 2013 foram a "dobra" que me fizeram pensar. Havia um abalo em junho que precisava ser assumido no fazer teológico. Era preciso dizer os desejos presentes nas ruas de 2013 e deixar vazar as "paixões ingovernáveis" do corpo qualquer, inclinado a outros corpos (em hostilidade/hospitalidade). Alianças para ir além da vida que somos forçados a viver e da cidade que somos obrigados a habitar em seu modo útil. Por isso, interpreto aqueles eventos como uma "dobradiça" político-teológica ${ }^{1}$ capaz de, em um lado, desvelar a assinatura teológica do estado moderno; e, do outro, apontar os potenciais profanatórios e destituintes do fazer-político moderno.

A suspeita que tenho é que os acontecimentos de junho de 2013 estão para além dos enquadramentos político-institucionais ou de um "poder constituinte" centrado nas polaridades que interpretam essas manifestações como uma ação da "esquerda" ou uma ação da "direita". Essas leituras incluem "junho" como grande esperança de reorganização das "esquerdas"; ou um movimento capturado pela "direita” e por grupos antidemocráticos 2. Para além de uma descrição dos acontecimentos de junho de 2013 nesse espectro, a hipótese que apresentei em minhas investigações de doutorado apontam que essas duas leituras enquadram junho na lógica produtiva da eficácia política. O que se esperava de junho? As polifonias provocam a vertigem ${ }^{3}$. Uma saída possível é a adequação do desejo nas práticas políticas e participativas de uma democracia liberal. Na cidade de São Paulo, por exemplo, o então prefeito Fernando Haddad (PT) tentou canalizar os afetos de junho para o Conselho da Cidade, um espaço de democracia participativa

Esse texto é uma versão adaptada de um dos tópicos da minha tese de doutorado - A revolta da ineficiência: os acontecimentos de junho de 2013 no Brasil e suas destituições políticoteológicas (2019), defendida no Programa de Pós-graduação em Ciências da Religião da UMESP. Nesse trabalho, essa discussão sobre junho como "dobradiça” está apresentada de maneira mais detalhada.

2 Para um aprofundamento sobre as leituras sobre junho de 2013, leia o capítulo "catados metodológicos" da minha tese de doutorado (SOUZA, 2019).

3 Sobre esse conceito para se analisar junho de 2013, confira o livro de Alexandre Mendes: MENDES, Alexandre. Vertigens de junho: os levantes de 2013 e a insistência de uma nova percepção. Rio de Janeiro: Autografia editora, 2018. 
construído em seu mandato. Uma tentativa interessante e prevista nas lógicas democráticas que constroem arranjos e conciliações para a formulação de políticas públicas, desde a tensão entre o que temos e que podemos ter. No entanto, na abordagem que assumo, junho coloca-se fora desse paradigma do "poder constituinte" e "poder constituído", marcas de leituras sustentadas nas reflexões filosóficas de Antonio Negri (2015). Para além dessa concepção, Junho é uma "potência destituinte" - conceito importante nas investigações de Giorgio Agamben (2017) - que pode favorecer o debloqueio do desejo para se imaginar outras "formas-de-vida”. Em relação à junho de 2013, interessa-me a seguinte afirmação de Vladimir Safatle: "tais manifestações são certamente o conjunto mais importante de revoltas populares da história brasileira recente, não por aquilo que elas produziram, mas por aquilo que elas destruíram" (SAFATLE, 2017, p. 107). Safatle apresenta uma intuição que se assemelha àquela que tenho pesquisado. Segundo ele, esses "acontecimentos não eram produzidos no interior de um trabalho de ação política contínua realizada por atores claramente definidos e representáveis" (SAFATLE, 2017, p. 114). Aqui está o ponto relevante para esse texto. As polifonias e incertezas em junho não se mostraram (e tinham essa intenção?) como programas incorporados na política transformada em técnica e em "boa gestão". Se as teologias da libertação (TdL) sempre buscaram construir possibilidades de vida mediadas por projetos práxicos-políticos, qual o impacto desses acontecimentos de junho de 2013 nas elaborações políticos-teológicas das TdL no Brasil?

De algum modo, esses "instantes" de junho escancararam e profanaram o estado moderno (atrelado ao capital) com os seus rastros destituintes; e, ao mesmo tempo, nos empurraram para a destituição de alguns deuses e deusas, para aumentar a potência de agir (e agir não). Acontecer é irrupção ou suspensão. Por isso, há algo de kairótico em junho de 2013. Uma brecha aberta no tempo ordinário para um novo uso do mundo, um novo uso da política. Dentre as distintas interpretações sobre aqueles eventos de 2013, como indicado, optei por seguir um caminho desde a noção de potência destituinte. Um poder não que acompanha todo ato. Uma potência impotente e inoperosa que se mantém nas revoltas. É como se nos liberássemos da urgência operativa da eficiência. Como definição, temos que a potência destituinte, para Giorgio Agamben, se relaciona com 
uma potência capaz de abandonar toda vez as relações teológico-políticas para que apareça entre seus elementos um contato (no sentido de Colli). O contato não é um ponto de tangência nem um quid ou uma substância em que os dois elementos se comunicam: ele é definido unicamente por uma ausência de representação, só por uma cesura. Onde uma relação é destituída e interrompida, seus elementos estarão em contato, pois é mostrada entre eles a ausência de qualquer relação. Assim, no momento em que uma potência destituinte exibe a nulidade do vínculo que tinha a pretensão de mantê-los juntos, vida nua e poder soberano, anomia e nomos, poder constituinte e poder constituído se mostram em contato sem relação nenhuma; por isso mesmo, o que havia sido cindido de si e capturado na exceção - a vida, a anomia, a potência anárquica - agora aparece em sua forma livre e não provada (AGAMBEN, 2017, p. 304-305).

A destituição abre o vazio como possibilidade de toda possibilidade. Evidenciar o contato é um exercício provisório para se desvelar o funcionamento da "máquina governamental", mas é preciso liberar a "vida", a "anomia", a "potência anárquica" da captura dos dispositivos de poder. Tentar sair dos paradigmas do direito e da lei. É a cesura, um corte com as relações estabelecidas e reificadas com o estado moderno, por exemplo. A destituição não se coloca no "cabo de guerra" em relação ao estado, mas ensaia uma desativação. Uma tentativa de esvaziar um modo de operação marcado pela totalidade que incorpora inclusive as possibilidades de rebelião. Ao destituir, os elementos estão dispostos, como que flutuando no campo de força governamental, não mais entre agentes de representação em espaços encenados de participação social. O que faremos com esses elementos postos? A partir da destituição ensaiar modos de vida com novos usos, novas práticas a partir daquilo que foi deixado nas ruas de junho de 2013. A questão é: até onde estamos dispostos a ir no exercício prático-teórico de libertação? Uma possibilidade de vida inoperosa que não se deixa capturar pelas programáticas teológicas e políticas que conhecemos nas últimas experiências de ocupação do estado na América Latina (dentre elas o próprio lulismo)?

Por isso, nessas provocações destituintes de junho de 2013, me deparo com a problemática dos modos de habitação do mundo, um inquietação ética. No exercício que proponho nesse texto, na “ética não há lugar para o arrependimento, por isso a única experiência ética [...] é ser a (própria) potência, existir a (própria) possibilidade; isto é, expor em toda forma a própria amorfia e em todo ato, a própria inatualidade" (AGAMBEN, 2013, p. 46). Na destituição nos encontramos no desconforto e no incômodo 
diante das perguntas mais pragmáticas da mobilização política. Mas também estamos na aventura alegre de contemplarmos a nossa própria possibilidade de viver, além do dever ser. Se cairmos na dinâmica constituinte - em uma herança da revolução francesa, como aponta o comitê invisível (COMITÊ INVISÍVEL, 2017, p. 91) -, seguiremos "o desejo de mudar tudo e o desejo de que nada mude", "são apenas algumas linhas e modificações simbólicas". Nessa lógica, "enquanto se discute as palavras, enquanto a revolução se formula na linguagem do direito e da lei, as vias de sua neutralização já são conhecidas e banalizadas" (COMITÊ INVISÍVEL, 2017, p. 92). A rebeldia já foi capturada, o fora "anárquico" foi integrado, neutralizado.

O problema posto, então, aparece nas palavras de Rodrigo Bolton, "como pensar uma política radicalmente profana, que não atenda nem a soberania nem a economia, senão uma política de uso?" (2017). Como criar formas-de-vida que nos coloquem para além da captura na soberania e exceção de um estado que produz vida nua (Giorgio Agamben) - uma vida sagrada que não pode ser sacrificada, mas pode ser morta? Como assumir a vida sem a "biopolítica da sobrevivência", a exceção que vira regra em todo campo e uma racionalidade neoliberal que a tudo quer abarcar, incluindo o desejo e a imaginação? Junho toca aqui. Um uso que tenta não ser capturável. Como os projetos políticosteológicos lidam com a destituição, o vazio? A ineficiência na teologia da Hibertação abre esse problema. Não mais o projeto político-histórico a seguir diante de um inimigo - com o nome que se queira inventar. $\mathrm{O}$ êxodo - potente como saida - foi cooptado como modelo e como programa. Cartilha pragmática. Um paradigma focado na identidade de um sujeito oprimido, no soberano libertador/conquistador, no povo/nação, na posse da terra e na operatividade da luta. Os rastros destituintes de junho me arrastam para um desprendimento desse esquema. Numa leitura desavisada, pode-se perguntar: sem o êxodo, por que ainda se falar em teologias da Hibertação ${ }^{4}$ ? Profanar, desde o pensamento de Giorgio Agamben (2007), é dar um novo uso. É isso que faço desde dentro desse caminho de espiritualidade a que chamamos de TdL.

O que me interessa nessa vivência espiritual: a ortodoxia ou a ortopráxis de tibertação? O que me inquieta é a "a paixão do povo que luta" - para

\footnotetext{
4 Nesse texto, sigo os rumos de libertação, mas como tibertação. Concordo com Fernando Candido: "o uso rasurado é intencional e segue o pensamento pós-moderno de revisão crítica de conceitos enredados por tramas ideológicas da modernidade", especialmente “devido ao seu enredo identitário" (SILVA, 2011, p. 6;11). Rasurar para criar outras possibilidades, desconstruir percursos e experimentar a língua.
} 
trazer uma provocação de Nancy Cardoso Pereira (2017). Os corpos de junho me deslocam para outros modos de pensar fora da prática esperada, da "doutrina" desejada. Redimir a palavra tibertação, liberá-la da sua operatividade constituinte. Talvez, aqui, encontremos uma dissolução de uma ética do dever ser (de tibertação). Uma radical abertura para um "livre uso de si", em que o hábito (ethos) "é a maneira que não nos ocorre nem nos funda, mas nos gera. E esse ser gerado pela própria maneira é a única felicidade verdadeiramente possível para os homens (sic)" (AGAMBEN, 2013, p. 35). Ser gerado na medida em que se coloca em movimento, em deslocamento. Novos hábitos, novos modos de viver, de estabelecer relações, de agir. Não um futuro de uma terra prometida que aprisiona possibilidades errantes para se dizer deus e fazer política. Como isso impacta as teologias da tibertação e os movimentos e arranjos políticos, especialmente no Brasil, que assumem as marcas dessa espiritualidade?

\section{ii. As teologias da libertação e os projetos históricos}

Quando Fernando Haddad (2017) escreve que as "modernas organizações contestatórias" "sempre foram adeptas de alguma mediação político-institucional", ele nomeia "organizações" que tem origem nesses movimentos de libertação, por exemplo, o MST ${ }^{5}$ e a CUT. Quando Gilberto Carvalho (2014) declara "que houve perplexidade no governo federal e até um sentimento de 'ingratidão' em relação aos manifestantes de junho de 2013: 'nós ficamos perplexos', esclarecendo que o 'nós' abrangia governo e "movimentos sociais tradicionais"” (Citado em ARANTES, 2014, p. 453), há também, aqui, movimentos que possuem uma "mística" de libertação. O próprio Partido dos Trabalhadores (PT) tem entre suas raízes a experiência dos movimentos das Comunidades Eclesiais de Base (CEB's) e da prática pastoral protestante ${ }^{6}$. Lula, em 2002, disse que "era fruto da Teologia da Libertação, dos sindicalistas..." (SALLES, 2004). E acrescenta: "ainda no interior tem uma base do PT muito fiel à sua origem, porque tem uma parcela da nossa base ligada à comunidade de base da igreja" (SALLES, 2004) ${ }^{7}$. Essa

Sobre isso, confira: LOWY, 2016, p. 225-232: “As origens sociorreligiosas do MST".

6 Sobre essa experiência, confira a atuação do CEDI - Centro Ecumênico de Documentação e Informação. Para isso, veja a dissertação de mestrado de Magali do Nascimento Cunha: CUNHA, Magali do Nascimento. Crise, esquecimento e memória - O Centro Ecumênico de Informação e a construção da identidade do Protestantismo Brasileiro. Dissertação de mestrado. UNIRIO, 1997.

Cf. o documentário Entreatos, informações na webgrafia dessa tese. Sobre a relação entre 
constatação se evidencia, por exemplo, na fala do bispo católico-romano Hipólito, de Nova Iguaçu (RJ): "para participar do processo social, o Povo precisa de instrumentos válidos e eficientes. Entre esses instrumentos estão, por exemplo, os sindicatos e os partidos políticos" (Citado em PINHEIRO, 2006, p. 209). Leonardo Boff também segue essa linha: a mensagem de Jesus, de um reino de justiça, aponta que era preciso estar ao lado dos "oprimidos e invisíveis", a "política seria uma mediação para alcançar tais bens para todos. Por isso, centenas de CEBs não entraram no PT, mas fundaram células dele e grupos como instrumento para a realização desse sonho" (BOFF, 2018, p. 93). A política, mediada na forma-partido, se transformou em um meio para um fim. Os partidos e sindicatos poderiam se colocar como instrumentos da "antecipação" do reino de Deus como um reino de justiça.

Claudio Ribeiro explica, em seu livro Pode a fé torna-se idolatria? (2010), como "a participação dos cristãos nos movimentos sociais e comunitários, e transformação social e construção do Reino de Deus são expressões recorrentes no interior das Igrejas" (RIBEIRO, 2010, p. 15). As teologias da libertação surgem a partir dos anos 1960 no contexto católico-romano (nas CEB's e nas pastorais setoriais) e no contexto pastoral protestante numa aproximação, também, com a chamada "teologia liberal" 8 (RIBEIRO, 2010, p. 15). Segundo Ribeiro, essas relações entre "fé e política” nesse mundo cristão "possibilitaram o estabelecimento de um grupo e de práticas 'progressistas', com a ênfase na 'construção' do reino. Tal perspectiva possui, direta ou indiretamente, a referência utópica do socialismo, que por seu turno, é também intra-histórica” (RIBEIRO, 2010, p. 16). Há vários textos que apontam para essa relação de "construção do reino de Deus" 9 como

TdL e o Partido dos Trabalhadores, veja: SANTOS, Jorge Pinheiro dos. O espectro do vermelho: uma leitura teológica do socialismo no Partido dos Trabalhadores, a partir de Paul Tillich e Enrique Dussel / Jorge Pinheiro dos Santos. São Bernardo do Campo, Universidade Metodista de São Paulo, 2006.

8 O liberalismo teológico, segundo Claudio Ribeiro, "foi encantador porque pregava o futuro que se avizinhava do presente. Acreditou-se que, de fato, 'o Reino de Deus está próximo'. Era possível construí-lo, ver sinais cada vez mais nítidos e crescentes de implementação do Reino. O ser humano é bom, é realizador; o mundo caminha para a paz sonhada; a educação, uma vez propiciada a todos, possibilitará evolução social, conscientização ética e justiça social. Orquestrando todo esse projeto utópico, estava a razão iluminista. A perspectiva teológica liberal, em síntese e como tendência, trouxe as expectativas escatológicas para dentro da história, acreditou na 'mão invisível' da educação e reduziu a espiritualidade à ética e ao seguimento de Jesus" (RIBEIRO, 2010, p. 15-16).

9 Para isso, confira os textos de Claudio Ribeiro (2010 e 2010b). 
O êxodo é (ainda) um paradigma político de libertação? 405 Algumas suspeitas filosóficas e teológicas desde junho de 2013

um projeto histórico. Agora, quero apenas indicar um momento mais recente em que essa relação se torna evidente.

Em 28 de novembro de 2014, após a eleição de Dilma Rousseff (PT), boa parte do grupo Emaús - composto, nas palavras de Frei Betto, "por pessoas ligadas à teologia da libertação no Brasil" - entregou uma carta à presidenta. Nesse texto intitulado O Brasil que queremos, encontrei trechos interessantes para a discussão que faço. Algumas marcas evidenciam o consenso de boa parte de uma determinada teologia da libertação com o projeto político do Partido dos Trabalhadores: "a maioria [de Emaús] batalhou, desde o início, em favor do PT e de seu projeto de sociedade", "tínhamos e temos a convicção de que a participação política, de cunho democrático, popular e libertador, se apresenta como um instrumento para realizar os bens do Reino de Deus" (JBF ${ }^{10}, 2014$, grifo próprio). Mas não há só consensos. A carta deixa rastros de dissensos no grupo de teólogas(os). "Discutimos e polemizamos", diz um dos trechos. O exemplo é que alguns integrantes do grupo não assinaram a carta ${ }^{11}$. Sabemos que os projetos políticos marcam as teologias da libertação. Mas não podemos falar de uma única leitura e perspectiva política. Existem diferenças sobre os projetos históricos.

Naquilo que vimos até aqui, desde o texto que analiso, podemos interpretar os projetos políticos como possibilidades e instrumentos desde que num viés "democrático, popular e libertador" - da realização do "Reino de Deus". Em decorrência dessa interação, os valores que guiam as "comunidades de base", que podem ser importantes na agenda política, são ditos na carta desse modo: "a centralidade dos pobres, a conquista da justiça social, a mútua ajuda, a busca incansável da dignidade e dos direitos dos oprimidos, a valorização do trabalhador e da trabalhadora, a justa partilha e o respeito pela Mãe Terra” (JBF, 2014). Nessa linha, e de maneira propositiva, a carta apresenta "algumas sugestões para que seu governo [de Dilma] continue implementando o projeto que tanto beneficia a sociedade brasileira, especialmente os mais vulneráveis" (JBF, 2014) ${ }^{12}$. Aqui vemos

10 Jornal Brasil de Fato.

11 Os integrantes de Emaús que não assinaram a carta para a presidenta Dilma: Faustino Teixeira, Ivo Lesbaupin, Francisco de Aquino Junior e Pedro Ribeiro.

12 Vemos a "reforma do sistema político" - "uma reforma que possibilite a participação dos cidadãos e cidadãs no processo de tomada de decisões"; o direito à cidade e a reforma urbana; um modelo econômico mais social e popular; a "reavaliação dos megaprojetos à luz de critérios ecológico-ambientais e sociais"; a defesa dos direitos de povos indígenas e quilombolas; a reforma agrária; a reforma tributária; uma outra política de segurança 
novamente a retomada e apoio ao projeto histórico liderado pelo Partido dos Trabalhadores, embora com dissonâncias e a apresentação de certas críticas em relação ao projeto desenvolvimentista que orienta os governos de Lula e Dilma.

A carta foi entregue a Dilma por alguns representantes desse grupo da TdL. Após o encontro, Frei Betto faz uma interessante narrativa veiculada na Radio Brasil Atual. Destaco alguns comentários. Entre as pautas elencadas por Frei Betto, retomo um pedido feito por esse grupo à presidenta: o "diálogo permanente com movimentos sociais, em especial com os jovens" (BETO, 2014). Talvez, aqui, encontremos um vestígio de uma provocação de junho nos discursos desses teólogos e teólogas da libertação. O encontro acontece depois das mobilizações de 2013. Em um texto lançado em 2018, Leonardo Boff cita os acontecimentos de junho. Para ele, essas "multidões de 2013" reclamavam por mais condições de viver minimamente feliz, como humanos e cidadãos, e não como meros consumidores passivos de bens postos no mercado" (BOFF, 2018, p. 92). E diz de maneira mais direta: "se um governo não cuida de seu povo, este tem o direito de não dar paz aos governantes" (BOFF, 2018, p. 93). Segundo Boff, o governo errou por não ouvir efetivamente aqueles acontecimentos de 2013, "tentou inicialmente, mas depois deixou-se tomar novamente pela política de conciliação" (BOFF, 2018, p. 93). Esse "presidencialismo de coalizão que marca o lulismo" se evidencia no próprio comentário de Frei Betto sobre o encontro com Dilma. Ele diz: "na saída da sala presidencial, eu encontrei um velho amigo, Robson Andrade, que é o presidente da Confederação Nacional da Indústria, e eu disse a ele - Robson, nós já falamos com a presidente dos direitos dos trabalhadores, e agora é sua vez de falar dos interesses dos patrões" (BETTO, 2014) ${ }^{13}$.

pública - que seja "exercida para proteger a vida e os direitos dos cidadãos, e não apenas a propriedade"; a universalização "dos direitos humanos, políticos, civis, econômicos, sociais, culturais e ambientais, com respeito à diversidade" - mas não se fala na carta, expressamente, da população LGBT; a garantia do "trabalho para todos/as. Trabalho digno e não precarizado"; "o controle social da gestão pública, para garantir um serviço público voltado para os interesses dos cidadãos"; e, por fim, a carta ainda indica que "nenhuma política baseada na corrupção levará a uma sociedade justa, democrática, solidária e equitativa. Uma outra política é possível, com punições exemplares e reforma de nossas instituições, de modo a coibir a impunidade" (JBF, 2014). Carta completa aqui: http://twixar.me/bCxK.

13 Sabemos das tensões de Frei Betto no governo. Nesse texto, há um relato sobre a sua saída e as suas impressões em relação à institucionalidade da política e os rumos do Partidos dos Trabalhadores: BETTO, Frei. A mosca azul: reflexões sobre o poder. Rio de Janeiro: 
O êxodo é (ainda) um paradigma político de libertação? 407 Algumas suspeitas filosóficas e teológicas desde junho de 2013

Jogos combinados na manutenção de uma "democracia dos consensos" e na manutenção do "pacto democrático" - em nome de toda governabilidade possível. O estado assume, como "máquina governamental”, um lugar de escuta dos "interesses" de uns e dos "direitos" de outros através de "alguma mediação político-institucional".

A construção das TdL - segundo Ignácio Ellacuria - tem como orientação fundamental a realização histórica (uma práxis) da salvação, a "transformação da realidade e, nela, a transformação da pessoa" (2000, p. 200). Por isso, a necessidade de se compreender que o objeto das teologias da libertação não está centrado em "Deus", mas na realização histórica do "reinado de Deus", naquilo que possui de reinado (dimensão histórica) e naquilo que possui de Deus (dimensão transcendente), em uma unidade profundamente radical (AQUINO JÚNIOR, 2012, p. 143). Com este compromisso práxico em buscar a concretude do reinado de Deus, as teologias da libertação tomam como elemento fundamental a crítica aos modelos de sociedade em que estamos inseridos, construídos como uma "civilização da pobreza", nas palavras de Ignácio Ellacuría (SOBRINO, 2008, p. 28-42). Por isto, procura imaginar novos modelos de sociedade. Com este movimento, tornou-se fundamental compreender que a criação e o discernimento de projetos políticos (históricos) passam a ser centrais em um pensamento de libertação. Considerações que estiveram presentes nas teologias, por exemplo, de Clodovis Boff e Leonardo Boff (1979; 1986), no coração da Guerra Fria, com a polarização entre capitalismo e socialismo. Neste contexto, teólogos da libertação, como os irmãos Boff e Gustavo Gutierrez, reconheceram o socialismo como um projeto político alinhado com as perspectivas de construção do reino de Deus, numa ruptura radical com a realidade marcada por injustiças. ${ }^{14}$

Aqui estamos no ponto crucial. Com uma relação umbilical entre teologias da libertação latino-americanas e o socialismo, ante a queda do muro de Berlim (1989) e a derrocada da União Soviética (URSS), a relação entre a teologia e este projeto político entra numa crise. Esta realidade foi analisada pelo teólogo Claudio Ribeiro (2010b), que sinaliza: a crise vivida pelas teologias da libertação depara-se, na primeira metade da década de

Rocco, 2006.

14 Para uma análise histórica e crítica deste processo, conferir: RIBEIRO, Claudio de Oliveira. A teologia da libertação morreu? Reino de Deus e espiritualidade hoje. São Paulo - Aparecida: Fonte Editorial - Santuário, 2010a; RIBEIRO, Claudio de Oliveira. Pode a fé tornar-se idolatria? A atualidade para a aAmérica Latina da relação entre Reino de Deus e história em Paul Tillich. Rio de Janeiro: Mysterium - Mauad X, 2010b. 
1990 , com a "ausência de um projeto global alternativo ao neoliberalismo" e com a "crise de paradigmas", com uma "perplexidade em diferentes áreas do conhecimento" (2010b, p. 12). Como sabemos, a teologia da libertação precisa ser compreendida como um movimento plural, como teologias da libertação (TdL) em processos de ruptura e continuidade (RIBEIRO, 2010b, p. 36-38). No âmbito metodológico, interessa-me o percurso realizado por Francisco de Aquino Junior (2010) e Claudio de Oliveira Ribeiro (2018) ao apresentarem as distinções de caminhos na TdL. No âmbito católico, o primeiro busca explicitar as tensões entre um "núcleo fundamental de ideias e intuições e uma diversidade de tradução e desenvolvimento desse núcleo na TdL latino americana" (AQUINO JUNIOR, 2010, p. 96). Ao estudar os católicos Gustavo Gutiérrez, Juan Carlos Scannone, Clodovis Boff, Juan Luis Segundo e Ignácio Ellacuría, Aquino Junior aponta "o primado da práxis e a perspectiva do pobre como as 'intuições centrais' ou a 'coluna vertebral' da TdL" (2010, p. 95). Daí decorrem traduções e novas perspectivas, mas desde um núcleo estruturante ${ }^{15}$. No fundo, se pensarmos leituras como a de Gustavo Gutierrez e Hugo Assmann, veremos que há uma busca por uma teologia que compreenda a "verdade" não como algo que acontece fora dos "eventos históricos", em que os seres humanos são seus agentes. Não há, portanto, conhecimento a parte da ação, do processo de transformação do mundo mediante a participação na história" (BONINO, 1977, p. 114). Aqui está a ruptura epistemológica com teologias mais próximas aos discursos de Bento XVI ${ }^{16}$.

Claudio Ribeiro procura analisar as raízes protestantes da teologia da libertação, estudando as reflexões de José Miguez-Bonino, Julio de Santa Ana, Rubem Alves, Elza Tamez e de Marcella Althaus-Reid. Sobre os aspectos teológicos enfatizados por círculos protestantes no contexto da TdL, Ribeiro sinaliza cinco traços: "a responsabilidade social cristã, a

15 Embora não seja o ponto central da minha discussão, cabe levantar uma suspeita sobre essa leitura de Aquino Junior. Onde estão as reinvenções na leitura desse núcleo central no "universo" católico da TdL? As falas de teólogas feministas que estavam também no processo inicial de construção da TdL Ivone Gebara vai apontar esse encobrimento: "fiz parte de todo esse movimento. Participei de muitos encontros nacionais e internacionais. $\mathrm{Li}$, estudei e dei aulas de teologia na linha da libertação. Junto com outros/as até redigimos a coleção "Teologia e Libertação"' (GEBARA, 2017, p. 21).

16 Para isso, confira a parte um do meu livro: Cristologia na encruzilhada (2016), especialmente as páginas 43-70. Aqui diálogo sobre as posições da Congregação para a Doutrina da Fé em relação à TdL. Nesse capítulo, também apresento leituras sobre a posição tomada por Clodovis Boff referente ao método da teologia da libertação e o lugar do pobre e da revelação. 
perspectiva ecumênica, a primazia da graça, a crítica profética em relação às formas idolátricas no campo sociopolítico e econômico e a eclesialidade de comunhão e serviço" (2018). Ao se falar na responsabilidade social, temos uma "primazia da práxis", com foco teológico nas "ações e as experiências no contexto de libertação social e política e as vivências eclesiais renovadoras que foram experimentadas" (RIBEIRO, 2017).

Sobre esse tema, destaco um importante livro do teólogo metodista José Miguez-Bonino: La fe en busca de eficacia: una interpretación de la reflexión teológica latinoamericana de liberación (1977). A eficácia já me chama a atenção. Em um dos trechos iniciais, Bonino destaca que o seu exercício em fazer TdL não é a construção de uma "escola teológica", embora - involuntariamente - isso vem acontecendo, o que resulta no "começo do seu pôr do sol" (BONINO, 1977, p. 10). Para Bonino, a TdL é, antes de tudo, uma tarefa, "a luta pela libertação". Essa luta se vinculava a um projeto, "um projeto socialista de libertação na América Latina" " ${ }^{17}$. Há aqui uma relação entre uma escatologia cristã (com a ênfase no Reino de Deus) e a visão marxista de futuro. Bonino retoma Engels e cita quatros semelhanças entre o movimento do cristianismo primitivo e o movimento socialista: 1 . foram movimentos compostos por gente oprimida; 2. anunciam uma salvação próxima e esperada da escravidão e da miséria; 3. são perseguidos, discriminados e desprezados; e 4. os dois avançam de maneira vitoriosa (BONINO, 1977, p. 161). Por todas essas relações, talvez, por isso Miguez-Bonino prefira chamar a TdL como uma teologia no contexto da luta por libertação ou teologia para a libertação (BONINO, 1977, p. 85).

\section{iii. As suspeitas e os limites de projetos históricos de libertação}

Os contextos são distintos. Há textos de teólogas e teólogos da libertação que indicam os limites dessas vinculações e relações diretas entre o horizonte do reino de Deus e a "luta por libertação" e os projetos históricos. Indico aqui alguns "aperitivos" críticos dentro da própria TdL. Claudio Ribeiro (Brasil), por exemplo, a partir do conceito de idolatria, elaborado por Paul Tillich, sinaliza o risco da absolutização de projetos históricos (como o socialismo), compreendendo-os como o reino de Deus (2010). Ao se vincular diretamente a "utopia" do Reino de Deus com o projeto

17 As principais marcas desse projeto são indicadas por Bonino em seu texto (1977), nas p. 65-66. 
político, pode se perder a experiência religiosa como experiência crítica. Aqui, destaca-se "a supremacia da dimensão institucional em detrimento da humana, a absolutização da perspectiva eclesiástica em relação à eclesial e a identificação do Reino de Deus com projetos intra-históricos” (2010, p. 18). Por isso, a proposta baseada no "reino de deus para além da história", em que se reconhece a práxis, mas sem abandonar o "reconhecimento dos limites humanos na realização dos sonhos" e "a capacidade de sonhar para além das condições humanas" (2010, p. 18).

A fala de Claudio Ribeiro se aproxima Juan Hernandéz Pico, de El Salvador. A sua obra "No sea asi entre ustedes: ensayo sobre politica y esperanza" (2010) é um texto significativo para se pensar os projetos históricos no âmbito das teologias da libertação. Pico procura compreender a articulação entre fé cristã e política para se vivenciar uma espiritualidade política. Para essa reflexão, toma algumas referências como o atual cenário global, como a crise econômica de 2008 e a vitória do capitalismo neoliberal. Quais saídas para essa realidade? Após realizar uma importante e sólida retomada das teorias de filosofia política, Pico apresenta uma política desde os subalternos, na ambiguidade entre o estado e a sociedade civil. Para isso retoma as memórias das lutas na América Latina, especialmente a América Central. Desde a dimensão bíblico-teológica, Pico realiza três importantes análises: das experiências de governos populares na América Latina e Caribe; da responsabilidade cristã pelo cuidado com a vida da Terra; e da tentação das esquerdas com o poder. Pico dialoga nesse último ponto com as reflexões críticas de Frei Betto e os seus relatos sobre a experiência do Partido dos Trabalhadores no governo - o risco de se "encantar" com o poder e assim abandonar as experiências de lutas populares ${ }^{18}$.

Outro autor, que realiza uma análise sobre os projetos históricos e a teologia da libertação, é Pedro Trigo, da Venezuela. O texto que me interessa é uma conferência, transformada em artigo, realizada na UCA em San Salvador. O título: "Repensar las izquierdas porque han fracasado y son necesarias. Un enfoque cristiano" (2016). Como o próprio nome já indica, o problema que Trigo apresenta é a própria falência das esquerdas. O interessante dessa provocação é perceber que mesmo nos setores marxistas, como aqueles associados à decolonialidade (TIBLE, 2013) ou à filosofia do direito (SOUSA JÚNIOR,

\footnotetext{
18 Além de $A$ mosca ažul, sobre esse processo de reavaliação de Frei Betto e análise crítica sobre os projetos históricos, cabe incluir o livro: Paraíso perdido: viagens ao mundo socialista (2015).
} 
2015), encontramos uma postura crítica para com o estado. O curioso é que essas leituras chegaram timidamente aos setores mais hegemônicos da TdL. Ou seja, as "mediações socioanáliticas" não foram muito bem "atualizadas". Nem mesmo o marxismo parece ter sido "atualizado" no escopo da teologia. Há aqui um resquício de um "método teológico" que assume um caminho epistemológico e o assimila praticando esse saber como se estivesse lidando com a própria revelação ou com os próprios “sujeitos de libertação", como os imaginários em relação aos "pobres".

Para além de uma saída rápida, Pedro Trigo procura apresentar essa realidade de fracasso. Mas sem perder o horizonte de necessidade de alternativas ao totalitarismo do mercado e da financeirização, em um cenário de "sequestro" dos imaginários, da política e da própria esperança. O seu interesse não é apenas no "socialismo real", mas também os partidos socialdemocratas que estão no poder. Segundo Trigo, "o fracasso mostrou que quando o Estado pretende substituir os demais agentes sociais e econômicos, mesmo que o faça com a melhor das intenções, porque pensa que os pontos de vista desses agentes estão interessados e que só ele cuida do bem comum, tudo desacelera" (TRIGO, 2016, p. 2). Abre-se, assim, um cenário em que "a situação se torna mais invisível do que a de uma injustiça óbvia que se pretendia reverter" (TRIGO, 2016, p. 2). Há uma captura pelo estado e um encobrimento das dinâmicas de desigualdade social. Embora o seu ponto de partida seja a realidade da Venezuela, suas intuições podem ser importantes para o diálogo sobre outras experiências. Trigo busca deslocar os projetos políticos de um antagonismo para uma simbiose,

Isso significa que, colocando-nos concretamente nesta história que temos que viver e em seu dinamismo, não aceitamos que o capital reduza o trabalho a uma magnitude quase residual. Não, claro, no seu desempenho concreto, mas nos direitos, como acontece hoje. Também não faz sentido que a classe empresarial desapareça, como pretendia o marxismo. Aceitamos as duas coisas, porque acreditamos que ambas são atualmente necessárias, mas não como antagonistas, mas na relação simbiótica, como em parte ela começou a acontecer no período pós-guerra (TRIGO, 2016, p. 2).

A leitura de Trigo compreende, desse modo, um outro deslocamento. De uma "luta de classes" à convergência de interesses e projetos, com a unidade na ação. Se ambos os atores - diz ele - "entram nesse horizonte, dão o máximo e transformam a competição para derrotar o outro na emulação, 
ou seja, cada um dos agentes se esforçará para dar de si o melhor do trabalho comum com frutos compartilhados" (TRIGO, 2016, p. 2). Pedro Trigo toma como referência a fala dos bispos em Medellin (1968), marco importante para a TdL no "mundo" católico romano, indicando que a fala do episcopado latino-americano se aproximava mais com uma proposta de simbiose que de antagonismo, numa superação da direção liberal e da direção marxista. Esse "para além" entende o caráter simbiótico como algo que "não exclui tensões ou conflitos. Além disso, oferece um horizonte onde estes podem ser processados, embora nunca sejam resolvidos definitivamente" (TRIGO, 2016, p. 17).

Marcelo Barros (2019), em correspondências trocadas comigo (14/01/19), aponta que a relação entre a TdL e os projetos históricos é um “tema difícil”, um assunto delicado. Segundo ele, "nos anos 60 até 80 havia uma sintonia e concordância geral, (todos/as os/as teólogos nossos - isso é, ditos da caminhada libertadora) estavam contra as ditaduras e tinham uma posição unificada, mesmo se uns eram mais explicitamente políticos e outros menos...." (BARROS, 2019). Para Marcelo Barros, alguns falavam a partir da inserção nos "cristianismos populares (Gustavo Gutierrez, Leonardo, etc)"; outros mais próximos à "modernidade secularizada (Juan Luis Segundo no Uruguai)"; no final dos anos 60, "Rubem Alves e Hugo Assmann mais em diálogo com a teologia da secularização (norte-americana e europeia)"; nos anos 80, "Jon Sobrino e Ignacio Ellacuría buscavam uma teologia política a partir da realidade de El Salvador, da luta de Monsenhor Romero em defesa dos pequenos e contra a ditadura e a guerra" (BARROS, 2019). Segundo ele, “atualmente não é assim". Não há essa "unidade" em relação aos projetos históricos e as suas relações com as teologias da libertação. "Há teólogos da libertação muito contra o governo bolivariano da Venezuela, (Pedro Trigo, por exemplo), contra o governo sandinista da Nicarágua (Jose Arguello, por exemplo)" (BARROS, 2019) ${ }^{19}$.

Essas leituras partem de uma "coluna vertebral da TdL" - "o primado da práxis e a perspectiva do pobre" - para de maneira plural, e às vezes antagônicas, compreenderem os projetos políticos. Penso que o projeto histórico pode ser um problema se assumido como horizonte e exemplo da prática presente. Assim, se prende o futuro em nome de um projeto a se sustentar. Como teleologia, a dinâmica de uma escatologia cristã e dos projetos políticos

19 Sobre a TdL e a experiência política da Venezuela, Cf. BARROS, Marcelo. Para onde vai Nuestra América? Espiritualidade socialista para o século XXI. São Bernardo do Campo:

Nhanduti Editora, 2011. 
O êxodo é (ainda) um paradigma político de libertação? 413 Algumas suspeitas filosóficas e teológicas desde junho de 2013

centrados na tensão entre o "já" e o "ainda não" fecha o futuro - em que o "já" pode ser a antecipação de um horizonte utópico e o "ainda não" como um modelo/projeto. Marcelo Barros, ao avaliar a postura de teólogos e teólogas da libertação em suas análises das experiências políticas que decorrem do "cristianismo de libertação", escreve: "acho lamentável que não se consiga distinguir as críticas que [se] têm a Maduro da defesa do Bolivarianismo, ou as críticas (justas) que os nicaraguenses têm contra a família Ortega da defesa que deveriam fazer do Sandinismo" (BARROS, 2019). Os horizontes do bolivarianismo, do sandinismo ou do lulismo podem ser clausuras que impossibilitam outros modos de viver e usar a política. Aqui está um risco nessa articulação entre teologia e práxis.

Se o "ainda não" pode ser uma promessa que aprisiona, uma possibilidade que assumo é "pensar o impensado" - modo que aprendi com os estudos de Giorgio Agamben - como uma possibilidade de liberar a potência de agir e de agir não, uma possibilidade de se abrir a toda possibilidade de uma vida liberada da captura e do abandono do estado neoliberal. Para esse exercício, apresento as reflexões de Nancy Pereira. Ao dialogar com os "primados" do pobre e da práxis, ela usa a metáfora do futebol e se pergunta sobre "o sujeito histórico da Teologia da Libertação: quem joga?" (PEREIRA, 2017, p. 45). Segundo Pereira, “o meu/nosso lugar de significado, entre a tradição de fé e teoria, não pode partir da teologia mesmo... nem da história da igreja, nem dos documentos de Concílios, nem Congressos e seus livros. Tudo isto é também TdL" (2017, p. 46). Mas o coração, o que faz pulsar, vem de outro lugar: a "ação concreta das maiorias oprimidas em processos de libertação”. Aqui ela estaria mais próxima das reflexões de José MiguezBonino, vistas antes. O resgate dessa "paixão do povo que luta" é importante "para que comentaristas, críticos, especialistas, narradores, técnicos, massagistas e dirigentes da teologia não expropriem nem reduzam as difíceis tarefas da TdL a estratégias pastorais datadas ou relicários imobilizados" (PEREIRA, 2017, p. 46). É o desafio de olhar os fracassos, as derrotas, as inquietudes cotidianas de quem quer organizar a vida e suas relações - em alianças, silêncios e rebeldias - sem se deixar engolir na tarefa do "desempenho" - agora medido pelo "ainda não" de um projeto histórico, como aquele vinculado à experiência do petismo (além do lulismo) ${ }^{20}$.

20 Para essa compreensão do petismo para além do lulismo, cf. MEDEIROS, Josué. Para além do lulismo: o fazer-se do petismo na política brasileira (1980-2016). Tese de Doutorado. Rio de Janeiro: UERJ, 2016. 
Aqui me coloco. Falo de tibertação, riscada. Eibertações rasuradas. Faço teologia como um ato segundo, máxima das teologias da libertação. Mas estou diante de um problema. De maneira hegemônica, as teologias da libertação em um movimento de espiritualidade - seguem a luta concreta como ponto de partida da teologia e o primado da práxis e do pobre. No entanto, construo uma leitura que sinaliza os acontecimentos de junho de 2013 como processos pouco eficazes, se pensarmos na "materialização" de utopias como projetos políticos e sonhos de um "reino de justiça"; com experiências marcadas por uma prática, mas sem se enclausurar na urgência do dever ser e na tarefa do "que fazer"; e com a atuação feita por corpos numa "singularidade qualquer", escancarando os limites da identidade do sujeito político.

Se junho de 2013, como uma dobradiça político-teológica, é capaz de desvelar a assinatura teológica do estado e de apontar os potenciais profanatórios e destituintes do fazer-político moderno, por meio desses acontecimentos, somos capazes de revisitarmos e analisarmos projetos históricos de teologias, como a latino-americana da libertação, e imaginarnos uma teologia da tibertação como uma teologia ineficiente. Ou dito de outro modo, como as paixões ingovernáveis de junho interpelam as TdL?

\section{iv. o êxodo como projeto e modelo político?}

As teologias latino-americanas da libertação foram construídas a partir do paradigma do êxodo. Embora alguns teólogos, como Gustavo Gutiérrez (1987), tenham proposto outras aproximações paradigmáticas (o êxodo vinculado à sabedoria), é sobre o esquema opressão-libertação que se organiza majoritariamente esse método teológico, esse modo de viver uma espiritualidade, esse modo de imaginar Deus e ensaiar programas políticos. Retomar esse paradigma me parece importante para se repensar os projetos históricos e as suas relações com o estado-nação e com os governos como nas ligações com o lulismo/petismo. De maneira direta, a suspeita que tenho é que o esquema do êxodo se relaciona com o imaginário do "poder constituinte" e "poder constituído" (Antonio Negri) - opressão-libertação e a posse da "terra prometida".

Nesse tópico, quero apontar o vazio do êxodo. Para isso, preciso, mesmo que de maneira pontual, reconstruir esse paradigma. Escolhi para o diálogo um importante artigo escrito por Enrique Dussel (1987) na revista Concilium, que sintetiza a constituição desse paradigma na teologia da libertação. No segundo momento, quero me aproximar das brechas do êxodo e dos seus desdobramentos no discurso teológico. 
O êxodo é (ainda) um paradigma político de libertação? 415 Algumas suspeitas filosóficas e teológicas desde junho de 2013

Dussel se recorda em seu artigo, que desde de 1967, os seus cursos no Instituto Pastoral Latinoamericano do CELAM, em Quito, se iniciavam com a exegese de Êxodo. Não só ele. Em diversos momentos, teólogos e teólogas da libertação voltaram aos textos do êxodo ${ }^{21}$. Essa aproximação não se dá apenas no âmbito teológico - se pensarmos de maneira estrita. Dussel relembra um trecho do hino sandinista na Nicarágua, que possui a expressão "terra onde mana leite e mel". Ou uma defesa de Fidel Castro, "a história me absolverá": "os cem mil agricultores pequenos, que vivem [em 1956] e morrem trabalhando numa terra que não é sua, contemplando-a, sempre tristemente como Moisés à terra prometida..." (DUSSEL, 1987, p. 99-100). Ao citar Rubem Alves (1970), Dussel assume uma fala do teólogo brasileiro que aponta o êxodo como "o paradigma para a interpretação de todo o espaço $e$ de todo o tempo" (1987, p. 101). É, desse modo, o "centro estruturante" da experiência histórica. Há a habitação no espaço e a vivência do tempo mediada pelo esquema "passado-Egito", "presente-Deserto", "futuro-terra prometida" (DUSSEL, 1987, p. 102). Um caminhar histórico do "povo de Deus" que possui “categorias fundamentais" (DUSSEL, 1987, p. 102): (i) o Egito com a classe faraônica (Ex. 1.8); (ii) os escravos explorados e justos (Ex. 1. 11); (iii) o profeta, Moisés (Ex. 2.1ss); (iv) o Deus que escuta e converte (Ex. 3.1ss); (v) a passagem pelo deserto, com as ambiguidades e as "provas" (Ex. 12. $37 \mathrm{ss}$ ); e (vi) a terra prometida (Ex. 3. 8). Esse movimento do "sistema de pecado" a Canaã se sustenta numa leitura que coloca em tensão a totalidade (Egito) e a exterioridade (deserto e terra prometida). Como aponta Gutierrez (1972), citado por Dussel: “a libertação do Egito é um ato político. É a ruptura com uma situação de despojo e de miséria e o inicio da construção de uma sociedade justa e fraterna. É a supressão da desordem e a criação de uma nova ordem" (Citado em DUSSEL, 1987, p. 103).

Estamos diante de um paradigma que acontece na tensão entre o "sistema de pecado" e o movimento de libertação que resultará em uma nova norma. No esquema construído por Dussel, podemos relacionar: "Faraó-Moisés-Deus" e "Egito-Deserto-Terra Prometida". Se resgatarmos as categorias dos teólogos e teólogas da "Escola do DEI", estamos em um

$21 \quad$ Entre os nomes indicados por Enrique Dussel, temos: Hugo Assamann (1973), Samuel Gotay (1981), H. Bojorge (1970), Andrés Lanson (1967), Pedro Negre (1970), Jorge Pixley (1973), R, Sartor (1971), Luis Rivera (1971), Porfirio Miranda (1971), Elza Támez (1979), Segundo Galileia (1982), Ignácio Ellacuría (1976), Ernesto Cardenal (1984), Severino Croato (1971). 
conflito entre um ídolo da morte (faraô) e o Deus da vida (Javê). Os ídolos são realidades históricas, que se fazem passar por divindades, com características de ultimidade, autojustificação, intocabilidade, promoção de salvação a seus adoradores, embora os desumanizem e exijam, sobretudo, vítimas para continuar a existir (SOBRINO, 1990, p. 32). O Deus da vida - como um Deus libertador - é a sua oposição. Ver o sofrimento do povo - como narrado em Êxodo - é, portanto, “'atentar', 'experimentar', 'co-participar', 'compartilhar'. Deus 'desce’ à ‘opressão de meu povo’ (v. 7)” (SCHWANTES, 1998, p. 26). Entre o ídolo e o Deus libertador, tem-se o profeta em sua tarefa de denúncia e proclamação da esperança. Entre o passado como Egito e a Nova Canaã como promessa, tem-se a passagem do deserto.

Jorge Pixley e Clodovis Boff, no livro Opção pelos pobres (1986), analisam o paradigma do êxodo. Pensemos no texto de Ex. 20. 2-3: "eu sou Javé teu Deus que te tirou da terra do Egito, da casa da servidão. Não terás outros deuses além de mim" (Bíblia de Jerusalém). Os teólogos comentam esse trecho indicando uma tensão entre o Deus Javé e os outros deuses possíveis. Mas essa não é a questão central, a existência ou não de outras divindades. O ponto importante se refere a esse povo criado a partir da libertação liderada pelo seu Deus. Nesse sentido, "todo Deus que não te tenha tirado da escravidão do Egito não pode ser teu Deus” (BOFF \& PIXLEY, 1987, p. 38). O povo é povo diante deste Deus. Há aqui uma esperança e uma unidade. Ao ser Javé, tem-se a singularidade de um Deus libertador que estabelece uma relação de dependência exclusiva, em que "o êxodo faz o povo de Javé” (BOFF \& PIXLEY, 1987, p. 38). Ao se celebrar a libertação e ao se imaginar com a terra prometida - de antes e de agora - busca-se reconstruir essas relações centradas no esquema "Javé é teu Deus". Ao ser assim, essa divindade sempre estará ao lado dos oprimidos de sua época. E por ter um lugar central no relato do Êxodo, essa "opção" "tem um caráter fundante para Israel, exerce uma influência básica sobre quase todos os materiais da Bíblia” (BOFF \& PIXLEY, 1987, p. 41). Uma ação/amor de Deus que privilegia os escravos do Egito, privilegia os pobres da Galileia na Palestina e todos os pobres (ou oprimidos) nos contextos mais diversos, como nos territórios da América Latina.

$\mathrm{Na}$ TdL, a tomada de consciência do paradigma do êxodo se deu em um processo construído de maneira comunitária, "a partir e a posteriori da práxis histórica do povo". Dussel indica cinco momentos dessa "tomada de consciência teológica": (i) a passagem de uma experiência pessoal e "subjetiva" 
da pobreza para a pobreza como exigência de toda Igreja, uma "igreja pobre" (a sua referência é o "mundo" católico-romano); (ii) a passagem da pobreza "subjetiva" como virtude ao caráter "objetivo" do pobre, o outro; (iii) a passagem do pobre descoberto na experiência espiritual do evangelho ao pobre como "classe", da "pobreza-virtude" ao "pobre-classe-povo"; (iv) a passagem do "pobre-classe-povo" como objeto de uma opção por ao "pobre-classe-povo" como sujeito da igreja e da história; e (v) passa-se a ler a Bíblia desde uma situação histórica concreta, um "Egito latino-americano" na busca de uma nova ordem histórica, que não é o reino final (DUSSEL, 1987, p. 104-106).

Jorge Pixley e Clodovis Boff apresentam um questionamento a essa compreensão de classe em Israel. "Não estaremos levando para tempos antigos um nível de consciência social que não era possível mais de mil anos antes da era cristã?" (BOFF \& PIXLEY, 1987, p. 41). A mediação assumida para a interpretação é oriunda de uma determinada "ciência social", uma "mediação sócioanalítica". A resposta é negativa. A saída dos dois autores é compreender o conflito ali instalado no Egito a partir da tomada de consciência dos camponeses (1987, p. 49). Em Canaã, tínhamos um contexto de "dominação egípcia que se refletia em lutas constantes entre os reis de suas cidades". Assim, "um deus/rei poderia substituir um outro como o 'benfeitor' que dava vida ao povo sem que nada houvesse mudado no próprio povo" (1987, p. 49). A lógica era a mesma. Aqui reside - na interpretação de Boff \& Pixley - um conflito entre campo e cidade. Buscava-se, desde a organização local, a construção de alternativas à lógica de dominação, uma tomada de consciência e um povo feito no movimento - contra o rei e a cidade. No Egito, na realidade de escravidão, o cenário é distinto. Tem-se "um só Estado e era um Estado muito forte com um apoio religioso muito convincente. Foi a necessidade de uma superexploração da base camponesa da sociedade para construções suntuárias que criou as condições para essa consciência" (1987, p. 49). Se em Canaã é possível encontrar alternativas - terras vizinhas e organização comunitária - no Egito, o Estado assume a vida como uma totalidade. Não há saída. Diante do Egito e seu "Deus supremo", surge Javé, "um deus dos pobres que prometia libertação". É a "luta dos Deuses" - frase que dá título a um importante livro de avaliação das teologias da libertação latino-americana ${ }^{22}$. Se não há saída no mundo, encontra-se uma alternativa transcendente que acampa a imanência. Um Deus

22 Cf. RICHARD, Pablo (org.). A luta dos deuses. Os ídolos da opressão e a busca do Deus libertador. São Paulo: Paulinas, 1982. 
que lança à libertação e a possibilidade de caminhar. Por isso, se funda ao redor de Moisés - com uma tomada de consciência - um grupo que desejava abandonar o "ídolo" e seguir a "promessa de uma outra terra onde corria leite e mel” (DUSSEL, 1987, p. 50).

O movimento construído por Dussel e as aproximações que fiz com Jorge Pixley e Clodovis Boff nos ajudam a compreender como esse paradigma foi abordado na TdL. Majoritariamente, o "êxodo" continua como modelo. Temos aqui um esquema estruturante na chave dialética opressão-libertação. Desdobra-se daí: o sujeito oprimido como categoria fundante (a identidade) mesmo que ampliado para além do "pobre-classe-povo"; a imagem de Deus - único - como aquele que decide sobre a libertação (o soberano); a criação de um povo como desejo e necessidade (a nação); a busca da terra prometida como horizonte máximo (a posse); uma práxis como exigência de atuação de um povo que segue vivendo no Egito, mas deve agir, andando com Deus, por sua própria libertação diante de todo faraó (a operatividade). ${ }^{23}$

23 Há outras leituras para além desse esquema que apresentei até aqui. Na filosofia política, por exemplo, o êxodo será assumido por autores como Antonio Negri e Michael Hardt (2000) e Paolo Virno (2001). Diante de um Império que governa o mundo, com todos os mecanismos nacionais e supranacionais, com processos globais de estabelecimentos de "não lugares", como construir alternativas e insurreições? Segundo Negri \& Hardt, o império é "uma ordem global, uma nova lógica e estrutura de comando - em resumo, uma nova forma de supremacia. O império é a substância política que, de fato, regula essas permutas globais, o poder supremo que governa o mundo" (NEGRI \& HARDT, 2006, p. 11). Contra essa lógica, temos a multidão de singularidades, uma mobilização que - através do 'êxodo' e da reinvindicação pela "cidadania global" - "reapropria-se do espaço que foi expropriando pelo capital ao longo da modernidade, criando "novos lugares" como espaços de liberdade" (ZUSMAN \& QUINTAR, 2001, p. 192). Falamos do êxodo, essa experiência de deserção, o deixar de obedecer, o colocar-se em saída, um "fora da medida". Saber achar a brecha, o limiar, a passagem. Irrupções. Fissuras inesperadas. Sem se negar o embate e o confronto, mas não se reduzindo apenas à essa lógica. Segundo Negri \& Hardt, as "batalhas contra o Império podem ser ganhas por subtração ou defecção. Essa deserção não tem lugar; é a evacuação dos lugares de poder" (2006, p. 232). Um êxodo dos lugares da realpolitk para se construir o comum. Não sem motivo, alguns textos potentes em suas análises sobre junho utilizaram essa "metáfora" de Negri \& Hardt - e da bíblia hebraica. Como por exemplo: A multidão foi ao deserto (2013) e Amanhã vai ser maior (2014). Paolo Virno contrapõe o êxodo e o estado. Ele dirá: "terreno de cultivo da desobediência são os conflitos sociais que se manifestam não só como protesto, mas sobretudo, como defecção (para falar como Albert O. Hirschman, não como voice, mas como exit)" (VIRNO, 2003, p. 41). O êxodo é esse exit. A possibilidade de sair, a coragem de desertar, "invenção desrespeitosa que altera as regras do jogo e enlouquece a bússola do adversário" (VIRNO, 2003, p. 41). Aqui temos leituras interessantes sobre o "paradigma do êxodo", colocando-o para além do "ainda não" que aprisiona, mas como um movimento, um deslocamento, com 
Ivone Gebara, desde (ou próxima) às teologias da libertação, também apresenta limites nesse paradigma. No seu texto Teologia ecofeminista (1997), ela indica que "antropocentrismo e monoteocentrismo se confundem e se distinguem num mesmo processo. Um depende do outro para viver" (1997, p. 44). O êxodo é um exemplo dessa lógica. O protagonista do texto (Ex. 3) é Deus, embora o "herói” seja Moisés. Espelhamentos de um "masculino". Segundo Gebara, o êxodo mostra uma "transcendência absoluta" em um "mundo imanente". Essa estrutura "leva-nos a uma organização sociopolítica fundada na transcendência absoluta de um Deus que parece influir diretamente no curso da História, embora nem sempre seja vitorioso" (GEBARA, 1997, p. 45). Parece ser uma justificativa para a "organização sociopolítica" que permanece em "uma estrutura hierárquica necessária à manutenção da ordem social". Nessa dinâmica, a partir de Phillis Trible, Ivone Gebara entende que muitos traços das ações de mulheres foram encobertos na Bíblia. "A História é compreendida como absolutamente dependente da vontade do Ser Supremo com imagem masculina" (GEBARA, 1997, p. 46). As grandes decisões políticas e sociais divinas se relacionam com o mundo masculino, enquanto o mundo doméstico - "território" das mulheres - "não entraria na grande aventura de fazer acontecer a justiça, a solidariedade e a paz. Ao contrário, é o lugar de violentos castigos de Deus. Exemplos típicos são a história de Eva e de Miriam, irmã de Moisés e Aarão" (GEBARA, 1997, p. 46).

Em outro texto mais recente (2017), Ivone Gebara escreve que em um contexto em que seguimos errantes, parecendo sem caminho "recordando dos tempos em que parecíamos ter o presente em mãos e, sobretudo no coração e na mente, os caminhos da futura libertação da América Latina...", a Tdl - "com todos os seus limites e grandezas", "tentou responder às perguntas circunstanciais do momento embora essas perguntas fossem

\footnotetext{
"exuberantes possibilidades" para além da "administração estatal" ou da busca do "recurso produtivo da empresa capitalista". Giorgio Agamben - perguntado sobre a expansão totalitária em escala global e aposta na negatividade, no silêncio e no exit - indica que não se sente "muito convencido" de que "o êxodo seja hoje um paradigma verdadeiramente praticável" (COSTA, 2006, p. 136). A suspeita de Agamben é que o "paradigma" do êxodo (multidão) - mesmo em saída - é "solidário" ao "paradigma do império". Voltamos a uma antinomia. A analogia assumida por autores como Negri \& Hardt está vinculada ao império romano e a sua contrariedade - a vida monástica. Hoje, diz ele: "o êxodo pode assumir somente formas subalternas e não é uma causalidade se termina pedindo ao inimigo imperial que lhe pague um salário" (COSTA, 2006, p. 136). Uma subalternidade no "lugar" esperado no esquema binário. Não significa tirar do êxodo a possibilidade de "modelos e reflexões", mas saber apontar nele a sua tensão binária que enclausura.
} 
também identificadas ao elenco das grandes e universais perguntas humanas" (GEBARA, 2017a, p. 22). Ao se apresentar os limites do paradigma do êxodo, não se encobre os desejos e a "hermenêutica da esperança" de pessoas que em suas "paixões ingovernáveis" lutavam e lutam por suas libertações pequenas, pontuais, ou como "metanarrativas" de um "ainda não" que segue no horizonte. É preciso levar em consideração os significados e os desejos contidos no chamado "paradigma do êxodo". Não é apenas uma questão de método ou quebra de paradigma, simplesmente, mas fala-se aqui sobre a organização da vida, a vivência de uma espiritualidade.

Nancy Pereira, em uma obra escrita comigo Ecumenismo: um grão de salvação escondido nas coisas do mundo (2014), faz uma análise do livro de Marc Ellis - Hacia uma teologia judia de la liberacion (1988). Há toda uma leitura crítica sobre o êxodo, que começo a indicar agora. Mas é preciso também - como faz Ivone Gebara - valorizar as nuances do texto, suas ambiguidades, suas potências. Nancy Pereira pegará o êxodo - "uma saída, uma passagem, uma eclusa - histórica, necessária, fantástica, definitiva e permanente”. Ela o compreende sem o idolatrar, como algo "fechado nele mesmo, refletindo no fundo o espelho que perpetua a vitimização e inviabiliza a passagem mesma" (PEREIRA, 2014, p. 128). Por isso, desde a aproximação com os nossos êxodos - desde "as vozes e as formas de resistência" que se "renovaram de memória libertadora e de santidade de toda a terra” (2014, p. 128) - é preciso encontrar/criar "teologias de janelas e pontes e não espelhos" (2014, p. 128). Aqui, talvez, esteja um limite de uma teologia da libertação mais hegemônica, que sinalizei até aqui, e sua imaginação do êxodo - como movimento, nomadismo e passagem para um modelo em que se enclausura projetos históricos, alimentando-os e sendo alimentado por eles. Abandonouse a possibilidade de passar, de transpor e salvar.

Com essa precaução sinalizada, concordo com Ivone Gebara que hoje, "algo diferente se descortina no horizonte, algo bem mais complicado e que pressinto não caber no referencial teórico e cultural da teologia da libertação do século XX”. Nancy Pereira também estaria de acordo (2017). Entre tantos pontos abordados por Gebara, destaco esse: "ser da teologia da libertação era acreditar num 'modelo' especifico de Deus” (GEBARA, 2017, p. 25). Segundo ela, uma certa "ortodoxia conceitual dogmática” da TdL se sustenta em "fixismo binário e hierárquico", algo criticado, por exemplo, por antropologias feministas, centradas da "relacionalidade, interdependência e mistura” (2017, p. 24). Mesmo nessa TdL - e a sua ruptura epistemológica 
- há marcas de que continuamos com a metafisica cristã como modelo, e "a partir dela deduzimos as posturas éticas justificadas a partir de uma ideia do bem segundo a vontade divina" (GEBARA, 2017, p. 24). Valoriza-se mais os "princípios" que emanam dessa "metafísica" que a vida cotidiana das pessoas. Algo próximo a crítica feita por Giorgio Agamben ao dever ser vivenciado no ofício e em certa liturgia do poder (2013).

O ponto decisivo em relação aos projetos políticos e aos modelos eclesiásticos de uma "igreja dos pobres" vem nesse questionamento de Ivone Gebara: “um Deus mais ‘flutuante e impreciso’ não ajudava muito uma compreensão da esquerda da sociedade, compreensão que vigorava na teologia da libertação" (GEBARA, 2017, p. 24). Era necessário um Deus libertador nos moldes soberanos de sempre, mas agora do lado dos pobres e escravizados, com o modelo dos camponeses de Canaã. Por isso, a teologia da libertação se construiu como "uma teologia rural" - dirá Marcella AlthausReid - e "a estrutura fornecida pelas comunidades camponesas foi às vezes privilegiada em detrimento das vidas dos pobres urbanos" (ALTHAUSREID, 2005, p. 17). Segundo Ivone Gebara, esse Deus de "esquerda" tinha planos para seu povo, tinha um catecismo a ser seguido e, sobretudo um instrumental de análise da realidade mais ou menos ortodoxo" (GEBARA, 2017, p. 24). Voltamos à problemática presente da relação entre TdL e os projetos históricos, com seus programas, suas táticas e estratégias e suas lideranças como "vanguarda". Quais imaginários de Deus essa luta constrói? Todas essas preocupações levantadas em 2017 já estavam presentes - no âmbito da teologia feminista - durante a década de 80 e nas seguintes, mas "não foram levadas a sério pelos teólogos da libertação que continuaram sua missão de serem também guardiões da tradição patriarcal e arautos de uma nova teologia" (GEBARA, 2017, p. 25). A problemática que aqui desenvolvo pode também ser um ensaio de profanação - dar novos usos no comum - aos saberes de determinadas teologias da libertação, sem se deixar levar pela absolutização de certos discursos.

Junto a essa crítica de Gebara, é importante retomar uma leitura que Robert Warrior fará do "paradigma do êxodo". No seu artigo: A native american Perspective: Canaanites, Cowboys, and Indians (1989), ele escreve de maneira decisiva:

Os personagens óbvios na história para os nativos americanos se identificarem são os cananeus, as pessoas que já viviam na terra prometida. Como membro 
da Osage Nation of American Indians, que se solidarizou com outros povos tribais ao redor do mundo, li as histórias do Êxodo com olhos cananeus. E é o lado cananeu da história que tem sido negligenciado por aqueles que buscam articular teologias de libertação. Especialmente ignoradas são as partes da história que descrevem o comando de Yahweh para aniquilar impiedosamente a população indígena (WARRIOR, 1989, p. 237).

A promessa como posse da terra prometida para um "povo-nação" diante de seu Deus pode representar o "aniquilamento" de um outro. Quando o cananeu sou eu, como lutar por libertação e caminhar junto a um Deus que "escuta o clamor" dos povos escravizados? O paradigma do êxodo pode ser utilizado nos modelos de colonização e hierarquização das vidas, corpos e territórios, como em relação aos povos indígenas dos Estados Unidos (ou do Brasil). Warrior apresenta que "a imagem libertadora de Yahweh não é completa", esse "Senhor, o libertador, tornou-se o Senhor, o conquistador" (1989, p. 236; 237). Milton Schwantes interpretava essa interação com os cananeus relacionando-os com o "sistema de pecado" do Egito. A terra já estava ocupada (como na promessa de Gn 12.4-9) por povos como assírios e babilônicos, identificados sobre a "cifra Canaã", "qualquer acordo ou convívio com estes senhores de impérios devastadores se tornou de todo inviável" (SCHWANTES, 1998, p. 27). Povos marcados pela "ganância" e pela "tirania". Por ser desse modo, dirá Schwantes: "já que é preciso sair do Egito para poder viver, também na terra da promessa não se poderá conviver com 'Canaã', pois essa tem a índole daquela" (SCHWANTES, 1998, p. 27).

Essa leitura retoma o esquema feito por Dussel: "Faraó-Moisés-Deus" e "Egito-Deserto-Terra Prometida". A provocação de Robert Warrior nos coloca no exercício de apontar os limites e os usos desse Deus que liberta e conquista, desse povo que é nômade e sonha com a posse da terra (com o aniquilamento dos outros), desse projeto que é de exclusão. A crítica de Warrior pode ser um bom parâmetro para se analisar as ações do Estado de Israel no território palestino, algo bem trabalhado por A. Mbembe, a partir de Regina Schwartz ${ }^{24}$, - violência e soberania "reinvindicam um fundamento

24 De Regina Schartz, há um texto interessante citado por Fernando Candido em sua tese de doutorado (2012): "Sim, e quanto os cananeus? E os amorritas, moabitas, hititas? Enquanto as narrativas bíblicas esboçam a criação, coesão e calamidades que abatem um povo a mando de seu Deus, o que acontece com todos os outros povos e seus deuses? Por muito tempo observando a Bíblia colocada a serviço do que eu não posso desculpar - aversão aos negros, judeus, gays, mulheres, "pagãos" e o pobre - eu começo agora 
divino: a qualidade do povo é forjada pela adoração de uma divindade mítica, e a identidade nacional é imaginada como identidade contra o Outro, contra outras divindades" (MBEMBE, 2018b, p. 42) ${ }^{25}$. A partir do êxodo - e o seu Deus - pode se legitimar a conquista imperial/colonial. A soberania de um Estado-nação - com suas políticas de segurança e "militarização", como encontradas no texto bíblico de I Samuel 8 - legitimadas pela soberania de um Deus que decide sobre a libertação.

Fernando Candido da Silva em sua tese de doutorado Uma aliança abominável e per/vertida? Anotaçoes subalternas sobre o arquivo deuteronômico (2011) segue essa mesma perspectiva: "o êxodo é tão somente o pontapé para a conquista" (SILVA, 2011, p. 6). A sua pesquisa - entre outras temáticas - investiga a "hermenêutica da libertação", o "programa da exegese latinoamericana", sustentada no binômio conflito/esperança. O texto de sua análise é o Deuteronômio (Dt), um livro que procura ativar a "memória do êxodo e da sociedade tribal e pré-monárquica em aliança com YHVH” (SILVA, 2011, p. 3). Uma interpretação desde o "paradigma do êxodo" busca encontrar no texto de Deuteronômio a "luta/reação contra práticas opressoras em favor de uma (nova) economia solidária e familiar” (SILVA, 2011, p. 3). Tudo está programado nas leituras desde esse "esquema": "opressão/libertação; injustiça/justiça; "faraó”/israelitas". Segundo Fernando Silva, "é dentro desta lógica dicotômica que surge o modelo da libertação. Deveras, sem esses binômios, a libertação passaria a não fazer sentido! Assim que a exegese latino-americana sempre tenta identificar o opressor para forjar a libertação do oprimido" (SILVA, 2011, p. 6).

\section{v. Provocações finais: um êxodo diagramático}

Do paradigma do êxodo - em sua leitura hegemônica - se desdobra, portanto, o soberano (como modelo de Deus), o povo-nação, a posse da terra como projeto, o pobre como sujeito histórico, o opressor como o ídolo e a operatividade como prática. Abordei esses temas nas análises críticas que

a ver alguma cumplicidade: a Bíblia sempre conta a história de um povo que herda às custas de alguém... Através da disseminação da Bíblia na cultura ocidental, suas narrativas tornaram-se o fundamento de um entendimento dominante de identidade étnica, religiosa e nacional, definidos negativamente contra outros" (Citado por SILVA, 2011, p. 46).

25 Sobre esse tema, também vale a leitura do texto de Nancy Cardoso (2014) - "Hacia una teologia judia de la liberación" - diálogos de santidade, memória e libertação desde América Latina" (p. 123-130) - presente no livro Ecumenismo: um grão de salvação escondido nas coisas do mundo. 
trouxe até esse momento. Uma rápida indicação de dissensos. Agora é preciso dar mais um passo. Liberar o êxodo, fazer um novo uso. Sair do "paradigma" como programa. Tatiana Roque, provocada pelos acontecimentos de junho de 2013, escreve um texto que me parece importante para essa parte final - Os novos movimentos se constituem a partir de diagramas (e não de programas)... (2015). Penso, nessa linha, que seja necessário ensaiar uma teologia ineficiente ${ }^{26}$, desde rastros e resíduos, imaginada como diagramas. Uma teologia que se deixe interpelar pelas polifonias e incertezas, pelos novos usos da política, com novos contatos, novas tramas, novas redes estabelecidas não a partir de um centro, mas em arranjos nas ruínas das imagens de um estado feito deus e de uma libertação construída como teleologia.

$\mathrm{O}$ que isso quer dizer?

A noção de diagrama é desenvolvida por G. Deleuze lendo M. Foucault $^{27}$. Pelos limites desse texto, que agora caminha para a sua costura "final", vou me deter só às aproximações e análises de Tatiana Roque. Segundo ela, "depois de junho, os momentos de maior potência dos movimentos foram aqueles em que diferentes lutas se encontraram, produzindo mobilizações imprevisíveis (professores e black blocs; garis e movimentos culturais)" (ROQUE, 2015). Há nesses acontecimentos e em junho, ainda que muitas instituições continuassem as mesmas, "o desbloqueio de um possível”. E "como o possível nunca está dado de antemão, não se exprime pelas forças políticas existentes, é somente um começo, algo que modifica a subjetividade, faz-nos vislumbrar novos caminhos" (ROQUE, 2015). Na linguagem que tenho assumido, parece que em junho se desbloqueia a possibilidade de toda possibilidade, imaginações do impossivel (algo tão

26 Esse exercício aparece com mais detalhes no capítulo 7 da minha tese de doutorado (SOUZA, 2019).

27 Caso queira aprofundar esse conceito e compreender as distinções entre Agamben, Deleuze e Foucault, leia o texto de Larissa Agostinho Diagrama ou dispositivo? Foucault entre Deleuze e Agamben (2017). O objetivo do seu "é resgatar a noção de diagrama presente em Foucault para diferenciar duas interpretações do conceito de dispositivo, a leitura de Agamben e a leitura que Deleuze faz de Foucault. A noção de dispositivo de Agamben diz respeito às positividades concretas que se inserem numa rede de poder. Pretendemos demonstrar que o conceito de Deleuze não deixa de lado outros aspectos do conceito foucaultiano, o dispositivo ou diagrama além de ser uma rede entre diversos elementos discursivos e não discursivos, é também mais geral que uma episteme, neste sentido ele contém elementos que não são totalmente capturados pelo poder, forças que não se deixam materializar em aparelhos de controle, sujeitos que não se deixam sujeitar ou que escapam das teias do poder" (AGOSTINHO, 2017, p. 6). 
teológico!), que abrem novos usos da cidade, dos corpos, da política.

Segundo Roque, "a dimensão diagramática é a dimensão do possível que emerge de uma ruptura política" (2015). Ou: a dimensão do impossível que surge de uma festa sabática ${ }^{28}$, uma destituição. Aqui também cabe a teologia - como a de libertação. O capitalismo e o estado seguem bem o seu regime semiótico - numa "democracia gloriosa". Palavras de ordem, marcas, logos, nos agenciamentos neoliberais ou nas "resistências populares". Desse modo, "o diagrama é uma maneira de pensar a repartição entre expressão e conteúdo sem passar pela representação, não apenas no nível político, mas no próprio âmbito da linguagem" (ROQUE, 2015). É destituir (redimir) a própria linguagem e a política da sua marca de representação. "O diagrama ignora a distinção entre conteúdo e expressão". Assim, não interessa inicialmente o que se quer dizer com "não vai ter copa" ou "não nos representa", essa são "expressões que produzem elos, que ligam pessoas (virtual ou fisicamente), que produzem mobilizações e protestos" (ROQUE, 2015). O "querer dizer" passa por agenciamentos, relações de força e poder, subjetividades. O que significa dizer deus? O que significa dizer libertação? Tatiana Roque afirma que "um acontecimento se produz tanto na dimensão da expressão quanto na dos corpos, ao mesmo tempo. E assim captamos o sentido daquilo que é dito" (2015). Desde os rastros que encontrei em junho vou tentando criar sentido para essas palavras e expressões político-teológicas.

No ponto de vista da política, um olhar desde o diagrama nos coloca diante das conexões - ou das habitações que nos levam além das binariedades de oposição em nossa vida ordinária. O diagrama está bem próximo daquela anotação do comitê invisível no livro Crise e insurreição (2016): “o mundo não nos rodeia, ele nos atravessa. O que nós habitamos nos habita. O que nos cerca nos constitui. Nós não nos pertencemos. Nós estamos agora e sempre disseminados por tudo aquilo a que nos ligamos" (COMITÊ INVISÍVEL, 2016, p. 94). Assim, estamos diante da emergência de forças (não de coisas), de potências (não de sujeitos), de elos (não só de corpos) (2016, p. 94). Nessa linha, concordo com Tatiana Roque: "trabalhar em termos de diagrama é desenvolver uma heterogeneidade de posições. Posições de grupo, posições sociais e mesmo posições em relação a si mesmo" (ROQUE, 2015). Por isso, falo em jogo, performance, brincadeira, processos de posicionamentos múltiplos.

28 No capítulo sete da minha tese de doutorado ("jogos de Hibertação: junho \& a ineficiência sabática”), essa relação entre êxodo e sábado está apresentada de maneira mais alargada. 
Uma pergunta que pode inquietar no final desse texto: mas há ainda alguma relevância em junho de 2013 para toda essa provocação às TdL? Há algo de junho para se compreender os recentes acontecimentos catastróficos da política latino-americana, como a eleição e o governo de Jair Bolsonaro (sem partido)? Junho permanece como um campo aberto. Um marco de uma série de convulsões sociais e políticas que, em disputas, acabaram reconfigurando e ressignificando os espaços institucionais de uma democracia liberal. Os estilhaços políticos da destituição ficaram gravitando no pós-2013. Agora, tento recombiná-los para se repensar práticas político-teológicas, especialmente desde as TdL. Como continuar montando em "vizinhança" e novas combinações esses estilhaços em diagramas? O "bolsonarismo" veio e montou um programa fascista, numa disputa pelos estilhaços e novos tipos de contato entre os elementos que restaram das destituições. Há alguma saída aqui? A minha suspeita: abandonar a lógica de um programa políticoteológico eficiente. Há a possibilidade ao liberar, no agir, a potência do não, que pode imaginar práticas e modos de atuação, práticas e movimentos de "diferenciação" - para além da soberania de deus e do sujeito, da identidade do agente histórico, da nação, da posse e da operatividade - como bem vimos no "paradigma do êxodo". O ponto decisivo é este: não assumir o êxodo como a saída para um programa, mas como a saída da necessidade de um programa que, em nome de uma promessa, enclausure a vida e as novidades de vida. Sair, desprender, deslocar, expandir a potência. Não mais a relação dialética - a busca do um, do todo. Uma fuga que estabelece novos elos, novos modos de viver. Pequenos e sutis. Habitar de outro modo o mundo e nossas inclinações e vinculações a outros corpos e à terra. Destituir não é se opor à instituição, não é se colocar numa "luta frontal", mas neutralizá-la, esvaziá-la em sua substância (COMITÊ INVISÍVEL, 2017, p. 98). Talvez, aqui, esteja um desafio para outros e novos agenciamentos de libertação.

\section{Referências}

AGAMBEN, Giorgio. A comunidade que vem. Belo Horizonte: Autêntica Editora, [1990] 2013.

Profanações. São Paulo: Boitempo, [2005] 2007.

. Opus Dei: arqueologia do ofício. São Paulo: Boitempo, [2012] 2013.

O uso dos corpos. São Paulo: Boitempo, [2014] 2017.

AGOSTINHO, Larissa Drigo. Diagrama ou dispositivo? Foucault entre Deleuze e Agamben.

Cadernos de Ética e Filosofia Política, (30), 6-19. 
O êxodo é (ainda) um paradigma politico de libertação? 427 Algumas suspeitas filosóficas e teológicas desde junho de 2013

ALTHAUS-REID, Marcella. La teología indecente. Perversiones teológicas en sexo, género y política. Barcelona: ediciones Bellaterra, 2005.

AQUINO JUNIOR, Francisco de. A teologia como intelecção do reinado de Deus: o método da teologia da libertação segundo Ellacuría. São Paulo: Edições Loyola, 2010.

Dimensão socioestrutural do Reinado de Deus. Escritos de teologia social. São Paulo: Paulinas: 2012.

ARANTES, Paulo. O novo tempo do mundo. São Paulo: Boitempo editorial, 2014.

BARROS, Marcelo. Para onde vai Nuestra América? Espiritualidade socialista para o século XXI. São Bernardo do Campo : Nhanduti Editora, 2011.

BETTO, Frei. A mosca azul: reflexão sobre o poder. Rio de Janeiro: Rocco, 2006.

Dilma recebe de Frei Betto e Boff carta com demandas de movimentos sociais. Rede Brasil Atual. 2014. Disponível: http://twixar.me/hlCK.

BOFF, Clodovis \& BOFF, Leonardo. Como fazer teologia da libertação. Petrópolis: Vozes/ Ibase, 1986.

Da libertação: o teológico das libertações sócio-históricas. Petrópolis: Vozes, 1979.

BOFF, L. Brasil: concluir a refundação ou prolongar a dependência? Petrópolis: Vozes, 2018. BOLTON, Rodrigo. O impensado como potência e a desativação das máquinas de poder. Cadernos IHU Ideias. ano 15. no 258. vol. 15. 2017.

CAVA, Bruno \& COCCO, Giuseppe (org.). Amanhã vai ser maior: o levante da multidão no ano que não terminou. São Paulo: Annablume, 2014.

CAVA, Bruno. A Multidão foi ao Deserto. Editora Annablume, 2013.

COMITÊ INVISÍVEL. Motim e destituição agora. São Paulo: N-1 edições, 2017.

COSTA, Flávia. Entrevista com Giorgio Agamben. Revista Departamento de Psicologia, UFF. 2006, vol.18, n.1, pp. 131-136.

CUNHA, Magali do Nascimento. Crise, esquecimento e memória - O Centro Ecumênico de Informação e a construção da identidade do Protestantismo Brasileiro. Dissertação de mestrado. UNIRIO, 1997.

DUSSEL, Enrique. Êxodo: Paradigma sempre atual. Concilium (209), Petrópolis: Vozes, 1987.

ELLACURÍA, Ignacio. La teología como momento ideológico de la praxis eclesial. Em: Escritos Teológicos I. San Salvador: UCA, 2000, 163-185

EMAÚS. Carta do Grupo Emaús à Presidente Dilma. Jornal Brasil de Fato. 2014. Disponível: http://twixar.me/bCxK.

ENTREATOS. Produção de João Moreira Salles. Rio de Janeiro: VideoFilmes, 2004 (117 min.). Disponível: https://bit.ly/2vEhNDm.

GEBARA, Ivone. Teologia ecofeminista. São Paulo: Olho d'água, 1997. 
- Teologia da Libertação e outras teologias na América Latina: desafios para hoje. Em: PARDO, Daylíns Rufín \& MARRERO, Luis Carlos (orgs.). Re-encantos y Re-encuentros: Caminos y desafíos actuales de las Teologías de la Liberación. Havana: Centro de Estudos Conselho de Igrejas de Cuba / Centro Oscar Arnulfo Romero, 2017, p. 21-33.

GUTIÉRREZ, Gustavo. Falar de Deus a partir do sofrimento do inocente. Uma reflexão sobre o livro de Jó. Petrópolis, RJ: Vozes, 1987.

HADDAD, Fernando. Vivi na pele o que aprendi nos livros. Revista Piauí. No. 129. Junho de 2017. São Paulo.

HARDT, Michael \& NEGRI, Antonio. Império. Rio de Janeiro: Record, 2006.

LOWY, Michael. O que é cristianismo de libertação? - religião e política na América Latina. São Paulo: Expressão popular/Fundação Perseu Abramo, 2016.

MBEMBE, Achille. Necropolítica. São Paulo: n-1 edições, 2018.

MEDEIROS, Josué. Para além do lulismo: o fazer-se do petismo na política brasileira (19802016). Tese de Doutorado. Rio de Janeiro: UERJ, 2016.

MENDES, Alexandre. Vertigens de junho: os levantes de 2013 e a insistência de uma nova percepção. Rio de Janeiro: Autografia editora, 2018.

MIGUEZ-BONINO, José. La fe en busca de eficacia: una interpretación de la reflexión teológica latinoamericana de liberación. Salamanca-Espanha: Sígueme, 1977.

MORAES, Alana et al. A periferia contra o estado? Para escapar das ciências tristes! Criemos outras possibilidades. 2017c. Urucum. Disponível: http://twixar.me/sH6K.

NEGRI, Antonio. O poder constituinte: ensaio sobre as alternativas da modernidade. Rio de Janeiro: Lamparina, 2015.

PEREIRA, Nancy Cardoso. "Hacia una teologia judia de la liberación" - diálogos de santidade, memória e libertação desde América Latina”. Em: PEREIRA, Nancy Cardoso \& SOUZA, Daniel Santos. Ecumenismo: um grão de salvação escondido nas coisas do mundo. São Paulo: Fonte editorial, 2014, p. 123-130.

Interrompidas venceremos! Rascunhos sobre libertação e fracasso. Em: PARDO, Daylíns Rufín \& MARRERO, Luis Carlos (orgs.). Re-encantos y Re-encuentros: Caminos y desafíos actuales de las Teologías de la Liberación. Havana: Centro de Estudos - Conselho de Igrejas de Cuba / Centro Oscar Arnulfo Romero, 2017c, p. 44-52.

PICO, Juan Hernández. No sea así entre ustedes: ensayo sobre política y esperanza. San Salvador, El Salvador: UCA Editores, 2010.

PIXLEY, Jorge \& BOFF, Clodovis. A opção pelos pobres. Petrópolis: Vozes, 1986.

RIBEIRO, Claudio de Oliveira. A teologia da libertação morreu?: reino de Deus e espiritualidade hoje. São Paulo/Aparecida: Fonte Editorial/Santuário, 2010.

Pode a fé tronar-se idolatria?: a atualidade para a América Latina da relação entre Reino de Deus e história em Paul Tillich. Rio de Janeiro: Mauad X e Instituto Mysterium, 2010 (a).

Teologia protestante latino-americana: um debate ecumênico. (No prelo). 
SAFATLE, Vladimir. Só mais um esforço. São Paulo: Três estrelas, 2017.

SANTOS, Jorge Pinheiro dos. O espectro do vermelho: uma leitura teológica do socialismo no Partido dos Trabalhadores, a partir de Paul Tillich e Enrique Dussel / Jorge Pinheiro dos Santos. São Bernardo do Campo, Universidade Metodista de São Paulo, 2006.

SCHWANTES, Milton. Fazer sair meu povo Israel do Egito: anotações sobre êxodo 3. Estudos de religião. n. 14, ano XII, julho de 1998, p. 23-33.

SILVA, Fernando Candido da. Uma aliança abominável e per/vertida?: anotações subalternas sobre o arquivo deuteronômico. Tese de doutorado. UMESP. São Bernardo do Campo, 2011.

SOBRINO, Jon. Fuera de los pobres no hay salvación. San Salvador (El Salvador): Uca editores, 2008.

Os seis jesuítas mártires de El Salvador. Depoimento de Jon Sobrino. São Paulo: Edições Loyola, 1990.

SOUSA JÚNIOR, José Geraldo (org). O Direito Achado na Rua: Concepção e Prática. Rio de Janeiro: Lumen Juris, 2015.

SOUZA, Daniel Santos. A “revolta da ineficiência": os acontecimentos de junho de 2013 no Brasil e suas destituições político-teológicas. Tese de doutorado em Ciências da Religião. Escola de Comunicação, Educação e Humanidades. Programa de Pós-Graduação em Ciências da Religião da Universidade Metodista de São Paulo (UMESP). São Bernardo do Campo, 2019. 349p.

Cristologia na encruzilhada: possibilidades de uma cristologia pluralista da libertação a partir de J. Dupuis e J. Sobrino. São Paulo: Editora Reflexão, 2016.

TIBLE, Jean. Marx selvagem. São Paulo: Annablume, 2013.

TRIGO, Pedro. Repensar las izquierdas porque han fracasado y son necesarias. Un enfoque cristiano. Revista latinoamericana de teología. Ano 2016, No 99, p. 223-240.

VIRNO, Paolo. Gramática da multidão - para uma análise das formas de vida contemporâneas. 2003. Disponível: http://twixar.me/ndCK.

WARRIOR, Robert Allen. A native American perspective: canaanites, cowboys, and Indians. Em: SUGIRTHARAJAH, R. S (org.). Voices from the margin: interpreting the bible in the third world. New York: Orbis Books, 1998, p. 235-241.

ZUSMAN, Perla \& QUINTAR, Aída. Contra-Império, éxodo y ciudadania global (sobre Negri e Hardt). Lua Nova. n. 53. 2001, p. 191-207.

Submetido em: 27-7-2020

Aceito em: 14-8-2020 